\title{
The future of 'Ghost Island' and the enduring legacy of late President Lee Teng-hui
}

Edition 5, 2021

Dr Roger Lee Huang

DOI: 10.37839/MAR2652-550X5.6

In one of Taiwan's most popular songs of this year, Ghost Island (鬼島), alongside Taiwanese rapper Dwagie, Malaysian singer-songwriter Namewee satirises the excesses of 'democracy and human rights' as 'gross impropriety,' welcoming listeners to a land where freedom of speech is 'blasphemy to the leaders.'

The song plays on the endearing yet self-depreciating slang for Taiwan, 'Ghost Island', which adeptly captures its wonderful contradictions: rowdy and confident which regularly punches above its weight internationally in the face of hostility from People's Republic of China (PRC, China), while consistently dejected for its exclusion from the international community. The song exudes pride in Taiwan's uniquely 'chaotic' democracy, but implicit is a sense of both despair and fear of an aggressively nationalistic China.

What Taiwan's democracy means today is deeply connected to the actions of the late President Lee Teng-hui, who died on July 30, 2020.

As both the first Taiwanese president of the Republic of China (ROC, Taiwan), and the first president to be directly elected via universal suffrage, Lee was instrumental in leading Taiwan to a peaceful democratic transition. Under his presidency, open discussions about Taiwanese identity, and the island's complicated relationship with China became possible. 
In 1998, during a campaign speech in support of Ma Ying-jeou's Taipei mayoral campaign, President Lee publicly spoke of the 'New Taiwanese' an idea rooted in civic-nationalist terms and deeply embedded as an essential part of Taiwanese democracy. The inevitable link between democratisation and self-determination naturally led to the emergence of a Taiwan consciousness inherently at odds with Chinese irredentism. While in office, Lee declined to endorse Taiwanese independence but in his later years, without the pressure and responsibilities of public office, he was explicit in his support for Taiwanese nationalism and backed a referendum for constitutional change in support of an independent Taiwan. It is therefore unsurprising, that Lee is considered a 'sinner' by both Chinese nationalists and the Chinese Communist Party (CCP).

Two weeks after the death of former President Lee, a retired entertainer known for her Han-Chinese chauvinistic views, defaced a portrait of the deceased statesman with red paint at the historic Taipei Guest House (臺北賓館). It probably did not occur to the defiant repeat offender, that her freedom to publicly criticise a former head of state was only possible due to the reforms introduced by the subject of her anger. A couple of years earlier, across the Taiwan Strait in Shanghai, Chinese dissident, Dong Yaoqiong was not so lucky. After livestreaming her public criticism of the CCP and splashing ink over an image of Xi Jinping, Dong was involuntarily committed for psychiatric treatment; a likely victim of China's infamous 'manufactured mental disorders' (被精神病).

The distinct treatment of these two women illustrates how far Taiwan and China's paths have diverged. Today, Taiwan is one of the most progressive, liberal states in the world, which champions a pluralistic society that even allows notorious gangsters to form political parties with a pro-China agenda. The CCP on the other hand, does not tolerate the mildest criticisms of its regime as it continues to harden its authoritarian control centred on the personalistic rule of its party chief and China's President Xi. 


\section{Taiwan under KMT rule}

It was not so long ago, that Taiwan, formally the Republic of China (ROC), was politically organised much in the same way as the PRC. The quasi-Leninist Chinese Nationalist Party (Kuomintang, KMT) subjected Taiwan to one of the world's longest martial law regimes. The halls of power in the KMT-ruled Taiwan were dominated by Chinese 'mainlanders' (外省人), those who had fled with Chiang Kai-shek from China in 1949 after their defeat by the CCP. For decades, the KMT maintained the myth that the ROC continued to exist as the legitimate government of China and transplanted all the trappings of its national government, including parliamentarians elected in China in the 1940s, to Taiwan. The KMT was quick to set a repressive approach in its relationship with Taiwanese society. The tragic 228 Massacre in 1947, was followed by a long White Terror reign which eliminated a generation of Taiwanese intellectuals and elites. Prior to becoming a KMT official, Lee experienced the KMT's terror campaign firsthand. In the 1960s, he was twice taken in by the fearsome Taiwan Garrison Command, and was subjected to intense interrogations. Under KMT-rule, 'Ghost Island' was not a forgiving place.

The KMT justified the suspension of civil and political rights in Taiwan through a complex web of legal instruments, notably the Temporary Provisions against the Communist Rebellion, while the notorious Article 100 of the Criminal Law criminalised any advocacy perceived to be pro-Taiwanese independence, which effectively suppressed the emergence of Taiwanese nationalism. The KMT systematically excluded local Taiwanese (本省人), which comprised more than 80 percent of the population, as well as the small indigenous population, from any significant position of power. In Lee Teng-hui's view first articulated in 1994 the KMT, like their Japanese predecessors were foreign regimes (外來政權) that had colonised Taiwan.

By the 1970s, it was clear that the KMT's long-declared aim to re-conquer China from the hands of the CCP was no longer grounded in any reality. In 1971, the 
United Nations General Assembly voted to "restore" the PRC as the lawful government of China and expelled Chiang Kai-shek's representatives' from the UN; by 1979, its security guarantor, the United States, had broken official ties with Taiwan in exchange for diplomatic relations with the PRC. Domestically, a new generation of dangwai activists (黨外) and non-partisan politicians, mounted serious challenges to KMT's non-democratic rule. Caught in a perilous situation and facing a legitimacy crisis both internationally and domestically, President Chiang Ching-kuo began to relax the KMT's long held repressive control of Taiwanese society.

As part of the response to demands for more Taiwanese representation in politics, Chiang, who had survived an assassination attempt by Taiwan independence activists in 1970, later introduced a localisation policy (吹台青) with the intended aim of co-opting Taiwanese youth and elites into the KMT. Lee, a trained agricultural-economist with a PhD from Cornell University, was recruited by Chiang in 1972 to serve in his cabinet as a minister without portfolio, responsible for agricultural affairs. Lee's meteoric rise within the ranks saw him promoted to several critical roles including Taipei Mayor (1978-1981), Provincial Governor of Taiwan (1981-1984), Vice President (1984-1988), and finally, Chairman of the KMT and President of the ROC (1988-2000).

The last dictator of Taiwan, Chiang-Ching Kuo may have initiated the early stages of political liberalisation by lifting martial law in 1987, just months before his death; but it was his successor Lee Teng-hui who is rightfully remembered as 'Mr. Democracy'. During his twelve-year presidency, Lee strengthened Taiwan's de facto existence as the "ROC on Taiwan," a democratic republic distinct from China. However this practical but temporary arrangement which stops short of formally declaring de jure independence means that Taiwan continues to be tangled up in the messy One-China policy. 


\section{Dismantling the KMT State and democratising the ROC}

Lee came into office through succession in 1988 following the death of Chiang Ching-kuo. Despite his later reputation as a political giant, the first Taiwan-born KMT Chairman and ROC President was initially written off by the KMT's old guard as a lame duck. The KMT's non-mainstream faction (非主流派), led chiefly by a group of mainland Chinese nationalists, were keen to prevent Lee's controls over the levers of power in the KMT party-state. Lee however shrewdly navigated the intricacies of KMT's factional politics. Through the strategic embracement of societal forces, and the implicit tolerance of the corrupt black gold politics, Lee ultimately fended off the non-mainstream faction's backlash, which eventually lead to the exodus of the most committed Chinese nationalists, who established the New Party.

The 1990 student-led Wild Lily movement (野百合學運) was a critical moment which allowed Lee to adopt and implement a democratic agenda. He banked on the zeitgeist of the 'democratic waves', and during his meeting with student representatives, promised that he would meet their demands for democratic reform, beginning with the convocation of a National Affairs Conference.

In sharp contrast to the CCP's violent 1989 crackdown of student-led protests in Beijing's Tiananmen Square only nine months earlier, Lee's positive reaction to student activism highlighted the very different type of consensual politics that would materialise during the remainder of his presidency. As opposed to the increasingly polarised political scene, following his exit from formal politics in 2000, Lee was able to work with a diverse group of stakeholders during his presidential tenure (1988-2000), which included academics, lawyers and opposition politicians from the Democratic Progressive Party (DPP), as well as Lee's allies and detractors from the KMT.

President Lee undertook several constitutional amendments and political reforms, 
unravelling the KMT's hold over the ROC state apparatus. In 1991, he formally repealed the Temporary Provisions against the Communist Rebellion, effectively ending the civil war against the CCP, and safeguarding Taiwanese citizens' political and civil rights through legal protections. A year later, the Taiwan Garrison Command that had terrorized a generation of Taiwanese was disbanded. The infamous Article 100 of the Criminal Code was also amended, decriminalising the promotion of Taiwanese independence. Lee also acknowledged for the first time the reality of two separate political entities, and that the Chinese 'mainland' was under de facto CCP administration. This was a significant departure of the idea of 'One China' perpetuated by the two Chiang dictators, who had long insisted that the KMT's ROC was the legitimate government of all of China, and that the CCP were unlawful 'communist bandits' (共匪). Lee also setup the National Unification Council, which released guidelines that listed the terms by which Taiwan could unify with China-conditions that set a particularly high bar such as requiring China to work together with Taiwan on an equal footing, and the need for a free and democratic China with respect to human rights and the rule of law. These changes sharply contrasted with Lee's predecessors' attitude of no-contact with the CCP. The easing of hostilities initially created a relatively cordial environment which allowed Taiwan and China to establish direct, semi-official channels of communication. The result was the so-called 1992 Consensus-where both sides allegedly agreed that there was only 'One China', although whether an actual consensus was ever reached, or what 'One China' meant, remains heavily contested.

Responding to the Wild Lily students' demands, reforms of the electoral system and political representation were also forthcoming. Having held their seats in defunct constituencies in China since the late 1940s, the 'ten-thousand year' (萬年國會) parliamentarians were finally forced into retirement in 1991 after a judicial ruling. The National Assembly was gradually phased out, and formally disbanded by 2005. By 1992, the Legislative Yuan took over the role as a unicameral national legislature, with fully elected legislators representing the ROC's de facto constituencies.

The façade of needing both a Central and a Provincial-level government to maintain 
the impression that the ROC was still the legitimate government of all of China was abandoned. Direct elections were gradually introduced at all levels of government from the mayoral level in 1994, to the Taiwan's highest office in 1996. These legal amendments and political reforms allowed Lee to indigenise the ROC state to reflect the reality of its jurisdiction as limited to Taiwan, as well as the offshore islands under the ROC's control. The lifting of authoritarian, societal controls and the end of KMT's monopoly over the narrative of Taiwan's identity further edged it towards the Taiwanisation of the ROC state apparatus.

Critically, with broad support from diverse societal actors, backed by judicial and legislative actions, Lee was able to neutralise the political ambitions of serving military officers and ensure that the armed forces were under the democratic control and oversight of civilian officials. This was demonstrated when Tang Fei became the first Chief of the General Staff in the history of the ROC to attend to the Legislative Yuan for interpellation. At the historical meeting in September 1998, Tang publicly stated that it was the military's responsibility to defend the Constitution, even if the Constitution was changed from the ROC to Taiwan. By the end of Lee's tenure as president, a National Defense Law was passed, formally asserting civilian supremacy of the military command.

\section{Pillars of Taiwan's democracy: a welfare and human rights regime}

Taiwan's resilient democracy is rooted not only in these political reforms but is also strengthened by Lee's efforts to build a more humane, progressive Taiwan. By the mid-1990s, President Lee had begun to actively work on restoring trust between the state and society. He directed state resources to promote grassroots initiatives and local cultural affairs as part of the 'Integrated Community-Building Program' (社區總 體營造), intimately linked to his view that the ROC citizenry was a 'community of shared fate' (生命共同體). Initially reluctant, Lee would later redress historical atrocities committed by the state including adopting a series of concrete measures 
to memorialise and compensate victims and families of the 228 Massacre, and other victims of past state violence. Although transitional justice has been a recurrent topic since Taiwan's democratisation, it was only in May 2018 that the Tsai Ing-wen government was finally able to establish a term-limited Transitional Justice Commission.

According to prominent indigenous activist and DPP politician Icyang Parod, it was President Lee's personal intervention that finally pushed through amendments to the Constitution allowing for the proper recognition of Taiwan's Indigenous people as 'Aborigines/Indigenous' (原住民) instead of the derogatory 'Mountain Compatriots'. A cabinet-level ministry the Council for of Aboriginal Affairs, later renamed as the Council of Indigenous Peoples, was also established in 1996, although a formal state apology for the mistreatment of the Indigenous population only became a reality two decades later in 2016 when President Tsai Ing-wen made an official state apology.

After the KMT's long neglect of local history and culture, Taiwan's educational curriculum also went through a series of critical reforms in line with Lee's push to normalise Taiwanese consciousness in the public sphere. One of the most tangible outcomes of mainstreaming is the introduction of the contested Getting to Know Taiwan (認識臺灣) textbooks into the public school curriculum in 1997; today Taiwanese students continue to learn about the history, society and geography of Taiwan in direct contrast with previous generation's China-centric education.

Finally, the National Health Insurance, recognised as one of the world's best public health systems, was implemented on March $1^{\text {st }} 1995$, five years earlier than originally planned at the personal insistence of President Lee. Despite initially facing strong opposition by labour groups and the health sector, the single payer universal health plan has proven to be remarkably successful in managing the COVID-19 pandemic. This is in part, related to the foundations of a strong cohesive society that emerged from Taiwan's pluralism and tolerance of dissenting views, with the Taiwanese public largely trusting of the government's efforts to combat the pandemic. 


\section{Taiwan's international status and addressing the 'China' issue}

The serious discussions about the government's responsibilities to its citizens, the debates about unification/independence and the emergence of socio-political pluralism inevitably led to conversations about Taiwan's status and its place in the international community. To counter the PRC's diplomatic victories, and to halt Taiwan's continued isolation from the broader international community, Lee adopted a pragmatic approach to diplomacy. Taiwan would no longer insist that its diplomatic allies adhered to the so-called One China principle or cut ties with the PRC.

The Lee administration also expanded Taiwan's unofficial international relations by increasing the number of representative offices in several countries usually in the guise of economic, social, and cultural affairs. This diplomatic modius vivendi has since become the common practice adopted by subsequent administrations from Chen Shui-bian to Tsai Ing-wen. In particular, the New Southbound Policy, the centrepiece of President Tsai Ing-wen's foreign policy agenda since 2016, is effectively a continuation and evolution of the direction that developed from Lee's "Go South" policy, first articulated in 1993; Lee's attempt to redirect the investment of Taiwan's private capital away from China to Southeast Asia. Another signature international campaign introduced during the Lee presidency was the push for ROC membership in the UN and the World Health Organization; a campaign that the Tsai administration has actively renewed since the advent of her presidency.

Although Taiwan-US relations have experienced ebbs-and-flows, Lee's efforts to actively engage the US during his tenure were critical to the rekindling of cooling relations since the breakdown of formal ties in 1979. The Lee administration reached out to international media and hired US lobby firms to appeal to the international community for its support of Taiwan's democracy, suggesting that China's 'reckless nationalism' is a threat to world peace and stability. Chinese adventurism, in 
response to Lee Teng-hui's US visit in 1995 to his alma mater, Cornell University, backfired significantly. The 1995-1996 Missile Crisis pushed the US to deploy a large navy presence near Taiwan's waters as it held its first democratic presidential election. Lee easily won with 54 percent of the popular vote in a four-horse race. Leaving aside official diplomatic relations, Taiwan's successful democratisation has further strengthened the bond between Taiwan and the US.

\section{Taiwanese democracy: The double-edged sword of 'Ghost Island'}

A year before leaving office, Lee publicly declared that Taiwan shares a "special state-to-state relationship" with China as political equals in a divided nation with two separate governments. This was interpreted by the Chinese Government as a twostate formula and in direct contradiction to China's preferred proposal of "one country, two systems," which is a highly unattractive proposition for Taiwan, especially given the evident collapse of this model in Hong Kong.

In the most recent poll conducted by the longstanding National Chengchi University's Election Study Center, a large majority, 67 percent of the people, identify solely as Taiwanese; 27.5 percent identify as both Taiwanese and Chinese, while 2.4 percent see themselves as only Chinese. The consistent, rising trend of those who identify as being Taiwanese however, does not fully capture the complex political position of the Taiwanese populace.

Although there is a broad consensus that Taiwan should at the very least maintain its status quo, there remains a myriad of opinions when it comes to addressing Taiwan's relations with China. These prevailing debates about Taiwan's status both in domestic and international circles will unlikely resolve in the foreseeable future. For the meantime, President Lee Teng-hui's articulation of the Republic of China on Taiwan remains the most viable modus vivendi. It appears that the incumbent President Tsai Ing-wen, who was one of the original architects of Lee's two-state 
theory, has re-adapted this concept in her lexicon, through her interchangeable use of Taiwan, ROC and the Republic of China Taiwan (中華民國台灣) in the 2020 national day celebration.

If China's current intensification of its controversial wolf warrior diplomacy and its aggressive actions in disputed territories is any indicator, then Taiwan's defiant democracy may be a double-edged sword. While Taiwan's democracy continues to serve as one its greatest defences against Chinese irredentist claims, a surge in Chinese nationalism is difficult to reconcile with Taiwan's new generation of proud ghost islanders, and could have serious implications for international peace and security.

Image: Current Taiwan President Tsai Ing-wen Former President Lee Teng-hui and, 26 August 2016. Credit: WikiCommons 